\title{
Pemasaran Pakan Cacing Berbahan Sampah Organik Menggunakan Fanspage Di Kecamatan Sukun Kota Malang
}

\author{
Aviv Yuniar Rahman ${ }^{1}$, Feddy Wanditya Setiawan ${ }^{2}$, April Lia Hananto ${ }^{3}$. \\ ${ }^{1}$ aviv@widyagama.ac.id, ${ }^{2}$ feddy @ polihasnur.ac.id, ${ }^{3}$ aprilia@ubpkarawang.ac.id \\ ${ }^{1}$ Program Studi Teknik Informatika, Universitas Widyagama Malang, \\ ${ }^{2}$ Program Studi Teknik Otomotif, Politeknik Hasnur Barito Kuala, \\ ${ }^{3}$ Program Studi Sistem Informasi, Universitas Buana Perjuangan Karawang
}

\begin{abstract}
With today's modern technology, the internet is a lifestyle for all people. In today's internet technology many people use Facebook as an alternative means of communicating. Facebook itself currently has a fanspage feature that is useful for users to follow. In this case, the aim is to market and introduce worm feed products from processed organic waste. Where the admin has been promoting worm feed products by carrying out 3 implementations periodically. In implementation 1 of 7 users who saw, 2 users who liked fans page, followed by 2 users who saw in detail. And 2 users who followed to continue the development of the worm feed fanspage. Then the second implementation is 22 users who see, 4 users have liked, 5 users who see the details and 4 users to continue to follow the fanpage page. In the third implementation, 31 users have seen it. 11 users like the page, 5 users have reached the fanpage page, 12 people have followed and 9 orders received in products marketed by worm feed fanspage.
\end{abstract}

Intisari-Dengan teknologi modern saat ini, internet merupakan sebagai gaya hidup seluruh masyarakat. Dalam teknologi internet saat ini masyarakat banyak menggunakan Facebook sebagai alternatif sarana untuk berkomunikasi. Facebook sendiri saat ini memiliki sebuah fitur fanspage yang berguna untuk diikuti pengguna. Dalam hal ini bertujuan untuk memasarkan dan memperkenalkan produk pakan cacing dari olahan sampah organik. Dimana admin telah mempromosikan produk pakan cacing dengan melakukan 3 pelaksanaan secara berkala. Dalam pelaksanaan 1 yaitu 7 pengguna yang melihat, 2 pengguna yang menyukai fanspage, Diikuti dengan 2 pengguna yang melihat secara detail. Serta 2 pengguna yang mengikut untuk terus perkembangan fanspage pakan cacing. Kemudian pelaksanaan ke 2 yaitu 22 pengguna yang melihat, 4 pengguna telah menyukai, 5 pengguna yang melihat detail dan 4 orang pengguna untuk terus mengikuti halaman fanspage. Pada pelaksanaan ke 3 yaitu 31 pengguna yang telah melihat. 11 pengguna menyukai halaman, 5 pengguna telah menjangkau halaman fanspage, 12 orang yang telah mengikuti dan 9 pesanan yang di terima dalam produk yang dipasarkan oleh fanspage pakan cacing.

Kata Kunci-Facebook; Pakan Cacing; Pemasaran; Fanspage

\section{PENDAhuluan}

Internet di era yang modern ini sebagai gaya hidup seluruh masyarakat saat ini [1]. Dalam jejaring internet saat ini telah berkembang dengan cepat dan luas [2]. Tak terkecuali Indonesia, masyarakat Indonesia saat ini pelaku utama yang berperan aktif dalam menggunakan fasilitas internet. Penggunaan internet pada saat ini sudah cukup mudah dan praktis untuk digunakan [3]. Sehingga perangkat elektronik sekarang sudah bukan barang yang berkategori mewah [4] Dalam teknologi internet saat ini masyarakat bisa mengakses informasi apa saja yang diinginkan, tak terkecuali media sosial [5] [6].

Media sosial saat ini merupakan salah satu alternatif dalam melihat sebuah informasi terbaru [7] [8]. Salah satu media sosial yang digunakan masyarakat Indonesia ini adalah Facebook [9]. Dalam penggunaannya Facebook merupakan alternatif sarana untuk berkomunikasi sesama pengguna dan untuk saling berbagi informasi [10]. Facebook sendiri saat in memiliki sebuah fitur fanspage, dimana fitur tersebut digunakan untuk berkumpul para komunitas dalam segala bidang yang ada di dalam fanspage Facebook [11]. Seperti contohnya komunitas para peternak cacing, saat ini para peternak bisa berkumpul dan bercerita tentang pengalamannya di halaman fanspage tersebut. Di dalam halaman fanspage pakan cacing ini juga sebagai sarana untuk pemasaran produk pakan cacing yang berasal dari olahan hasil sampah organik. Dengan pemasaran ini akan mempermudah para peternak cacing dalam mencari pakan [12][13]. Dalam mencari pakan cacing memang tidak sulit untuk didapatkan, namun untuk menghasilkan cepatnya berkembang pada cacing diperlukan pakan yang bagus dan bermutu untuk menghasilkan cacing yang bermutu dan bernilai jual tinggi. Seiring berjalannya waktu fenomena komunitas fanspage pakan cacing semakin hari semakin meningkat. 


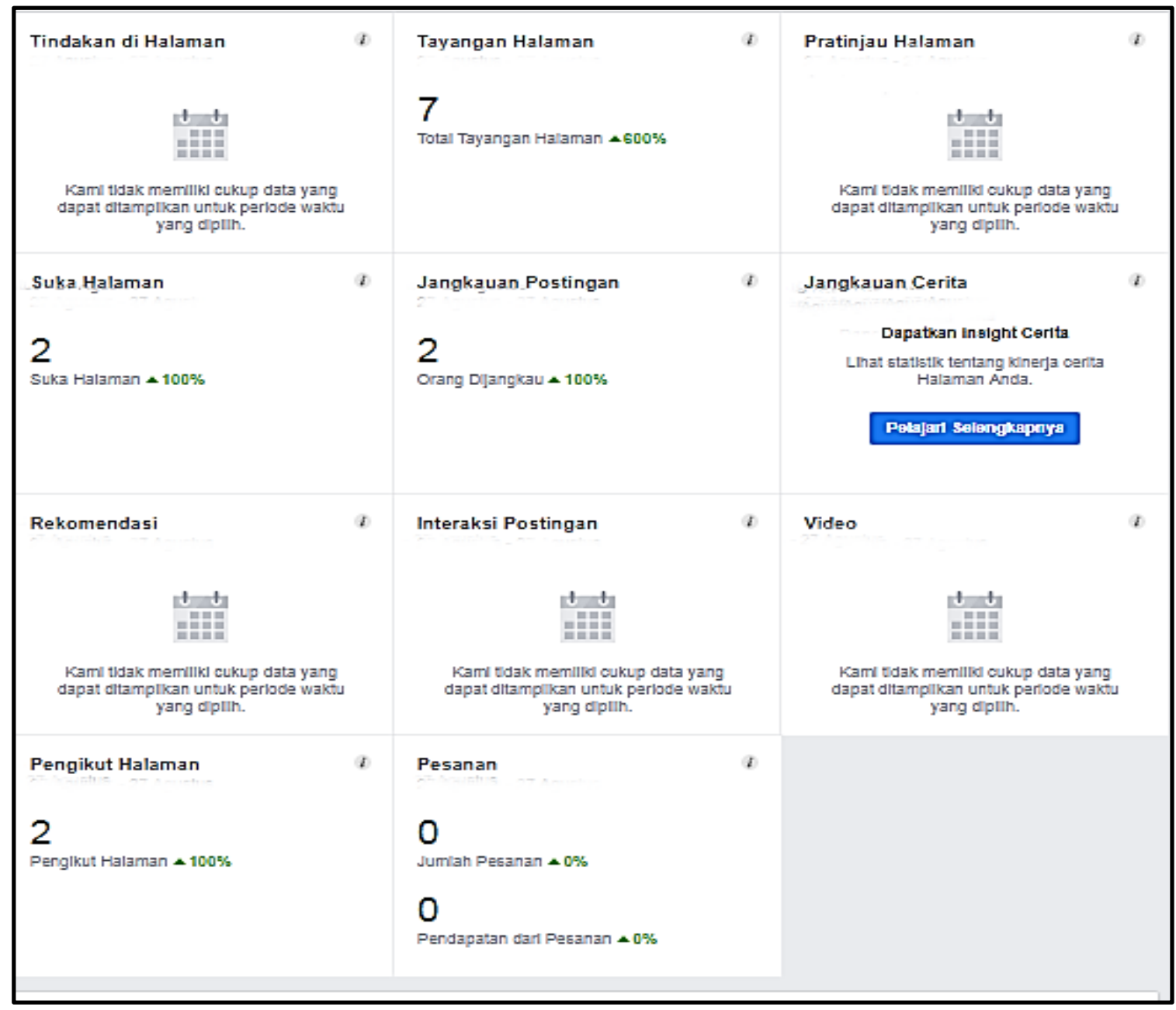

Gambar 1. Pelaksanaan 1

Kota Malang contohnya, diketahui di kota tersebut banyak para peternak pemula yang memulai usaha ini [14]. Dalam hal ini akan mencoba meningkatkan perekonomian merek dalam memulai usaha baru. Di Kecamatan Sukun salah satunya, banyak masyarakat tersebut mencoba untuk memulai usaha peternakan cacing. Dalam usaha peternakan cacing ini tidak membutuhkan ruang yang besar. Hal ini yang menjadikan peternak pemula untuk memulai usaha tersebut. Diketahui dalam peternakan cacing ini para peternak cacing di Kecamatan Sukun mengalami kesulitan dalam mencari sebuah pakan cacing. Ini dikarenakan kurangnya tentang penerapan yang mengenai pemberdayaan dan budidaya cacing [15].

Dalam hal ini dilakukan penerapan dengan menggunakan sampah organik sebagai media alternatif untuk pakan cacing. Penerapan ini dilakukan melalui media sosial fanspage Facebook dengan tujuan memasarkan dan memperkenalkan produk pakan cacing dari olahan sampah organik. Selain itu bukan hanya bisa diketahui oleh masyarakat yang berada di Kota Malang saja, namun untuk semua orang yang telah mengikuti halaman fanspage pakan cacing.

\section{METODE PENELITIAN}

Dengan hal ini akan memberikan sebuah rancangan yang akan digunakan dalam proses, serta menjelaskan beberapa tahapnya seperti:

\section{A. Lokasi}

Lokasi dalam pelaksanaan ini yaitu halaman Facebook. Dimana di dalam halaman Facebook akan memanfaatkan fitur fanspage untuk berkomunikasi dengan antar pengguna lainnya.

\section{B. Khalayak Sasaran}

Dalam sasaran ini ditujukan kepada masyarakat, khususnya para peternak cacing pemula maupun yang sudah memiliki pengalaman. Dalam tahap ini akan memberikan sarana untuk para peternak agar bisa saling berpendapat dalam usahanya. Serta sebagai metode sarana untuk pemasaran,

\section{Metode Pengabdian}

Dalam pengabdian ini menggunakan metode online. Dimana metode online ini dilakukan untuk pemasaran pakan cacing berbahan sampah organik.

\section{Metode Pelaksanaan}

Tahap ini dibuat beberapa pemasaran untuk dipantau setiap perkembangannya. Dalam perkembangan postingan tersebut nantinya akan di analisa untuk bahan pertimbangan. Dalam pelaksanaan yang pertama dengan membuat sebuah postingan di halaman fanspage yang dari pelaksanaan tersebut seperti pada Gambar 1. 


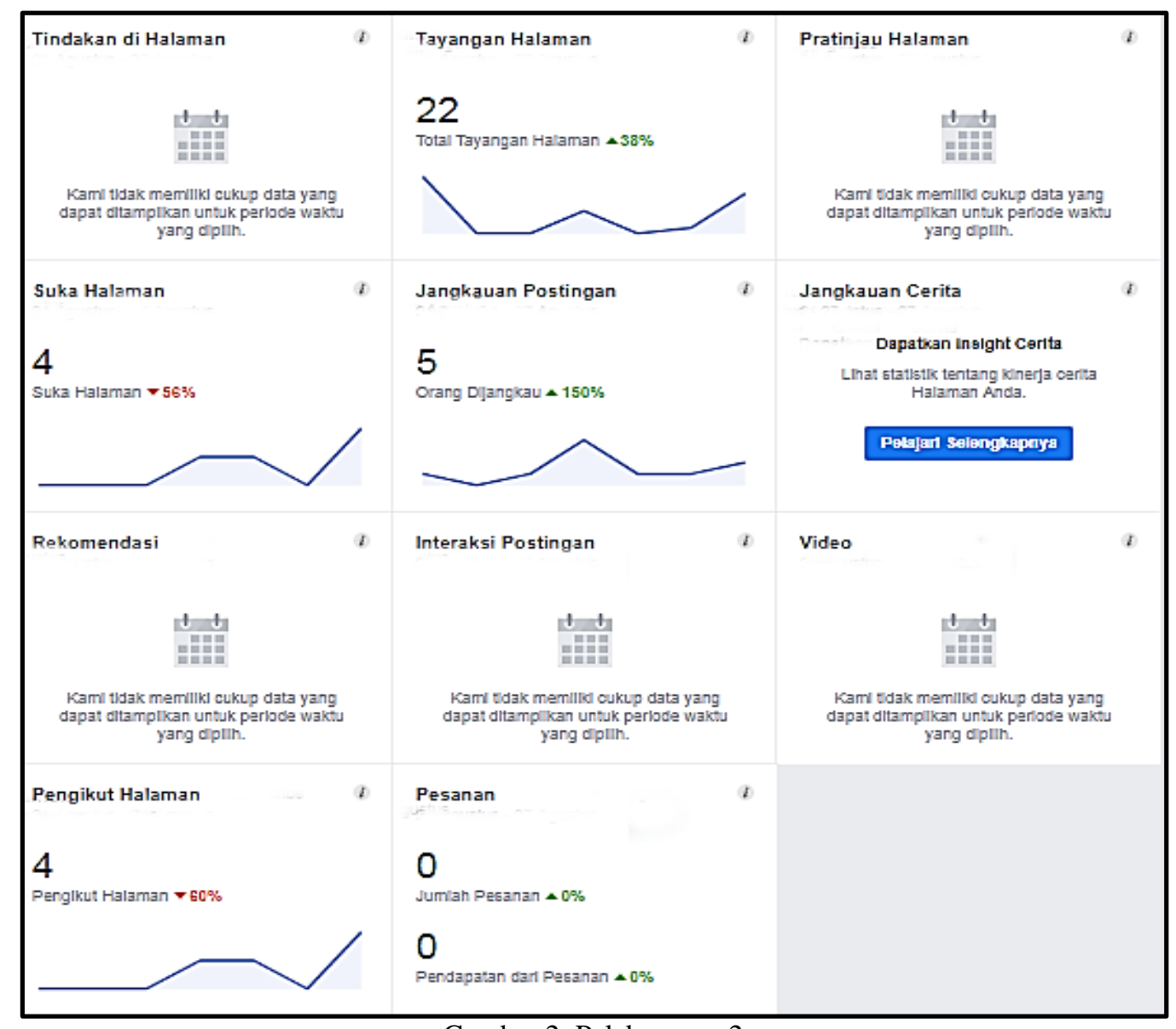

Gambar 2. Pelaksanaan 2

Pada Gambar 1. Merupakan pelaksanaan yang pertama, terdapat pada kolom "Tindakan di Halaman" adalah hasil dari tindakan pengelola akun dalam ajakan ke pengguna lain. Selanjutnya yang terdapat dari kolom "Tayangan Halaman" dimana tayangan tersebut adalah pengguna yang telah melihat halaman tersebut. Dari tayangan halaman tersebut diketahui hasilnya adalah 7 tayangan berarti 7 tayangan. Dalam kolom "Pratinjau Halaman" merupakan orang yang telah mengarahkan ke halaman tersebut. Di dalam kolom "Suka Halaman" ada 2 orang yang menyukai halaman tersebut. Dalam "Jangkauan Posting" ada 2, yang mana dalam jangkauan tersebut merupakan jumlah orang yang memiliki postingan dari halaman tersebut. Kemudian dari kolom "Jangkauan Cerita" terdapat hasil dari jumlah orang yang memiliki cerita dari halaman tersebut. Dalam kolom "Rekomendasi" ini merupakan hasil dari beberapa orang yang telah merekomendasikan halaman tersebut. Untuk kolom "Interaksi Postingan" merupakan isi dari beberapa orang yang telah berinteraksi dari halaman fanspage tersebut. Seperti mencoba menyukai halaman, mengomentari halaman dan berinteraksi lain mengenai halaman tersebut. Di dalam kolom "Video" merupakan hasil tayangan dari video dengan durasi minimal 3 detik. Serta dalam kolom "Pengikut Halaman" terdapat 2 orang yang telah mengikuti halaman tersebut dan pada kolom "Pesanan" merupakan hasil dari beberapa pengguna yang mencoba memesan hasil dari produk halaman fanspage tersebut.

Pada Gambar 2. Merupakan pelaksanaan yang kedua, terdapat pada kolom "Tindakan di Halaman" adalah hasil dari tindakan pengelola akun dalam ajakan ke pengguna lain.
Selanjutnya yang terdapat dari kolom "Tayangan Halaman" dimana tayangan tersebut adalah pengguna yang telah melihat halaman tersebut. Dari tayangan halaman tersebut diketahui hasilnya adalah 22 tayangan berarti 22 tayangan. Dalam kolom "Pratinjau Halaman" merupakan orang yang telah mengarahkan ke halaman tersebut. Di dalam kolom "Suka Halaman" ada 4 orang yang menyukai halaman tersebut. Di dalam kolom "Suka Halaman" terdapat penurunan grafik dimana hasil dari penurunan tersebut adanya pengikut yang mencoba membatalkan suka pada halaman. Dalam "Jangkauan Posting" ada 5, yang mana dalam jangkauan tersebut merupakan jumlah orang yang memiliki postingan dari halaman tersebut. Kemudian dari kolom "Jangkauan Cerita" terdapat hasil dari jumlah orang yang memiliki cerita dari halaman tersebut. Dalam kolom "Rekomendasi" ini merupakan hasil dari beberapa orang yang telah merekomendasikan halaman tersebut. Untuk kolom "Interaksi Postingan" merupakan isi dari beberapa orang yang telah berinteraksi dari halaman fanspage tersebut. Seperti mencoba menyukai halaman, mengomentari halaman dan berinteraksi lain mengenai halaman tersebut. Di dalam kolom "Video" merupakan hasil tayangan dari video dengan durasi minimal 3 detik. Serta dalam kolom "Pengikut Halaman" terdapat 4 orang yang telah mengikuti halaman tersebut. Diketahui bahwa hasil dari pengikut halaman tersebut menurun karena adanya yang mencoba membatalkan untuk mengikuti halaman kemudian mengikuti lagi. Dan pada kolom "Pesanan" merupakan hasil dari beberapa pengguna yang mencoba memesan hasil dari produk halaman fanspage tersebut. 


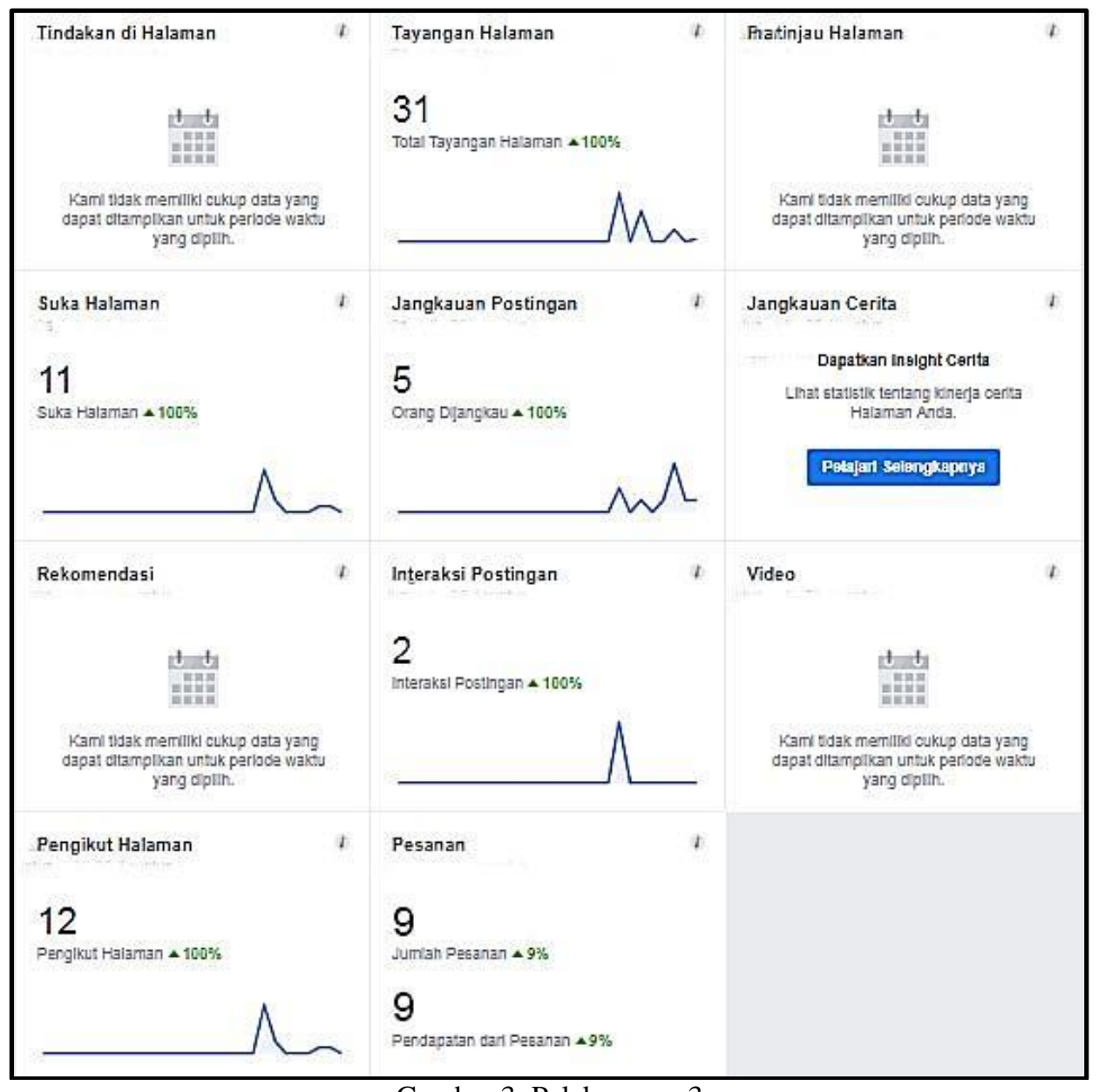

Gambar 3. Pelaksanaan 3

Pada Gambar 3. Merupakan pelaksanaan yang ketiga, terdapat pada kolom "Tindakan di Halaman" adalah hasil dari tindakan pengelola akun dalam ajakan ke pengguna lain. Selanjutnya yang terdapat dari kolom "Tayangan Halaman" dimana tayangan tersebut adalah pengguna yang telah melihat halaman. Dari tayangan halaman tersebut diketahui hasilnya adalah 31 tayangan berarti 31 tayangan. Dalam kolom "Pratinjau Halaman" merupakan orang yang telah mengarahkan ke halaman tersebut. Di dalam kolom "Suka Halaman" ada 11 orang yang menyukai halaman tersebut. Dalam "'Jangkauan Posting" ada 5, yang mana dalam jangkauan tersebut merupakan jumlah orang yang memiliki postingan dari halaman tersebut. Kemudian dari kolom "Jangkauan Cerita" terdapat hasil dari jumlah orang yang memiliki cerita dari halaman tersebut. Dalam kolom "Rekomendasi" ini merupakan hasil dari beberapa orang merekomendasikan halaman tersebut. Untuk kolom "Interaksi Postingan" merupakan isi dari beberapa orang yang telah berinteraksi dari halaman fanspage tersebut dan menghasilkan 2 orang yang mencoba untuk berinteraksi dengan halaman. Seperti mencoba menyukai halaman, mengomentari halaman dan berinteraksi lain mengenai halaman tersebut. Di dalam kolom "Video" merupakan hasil tayangan dari video dengan durasi minimal 3 detik. Serta dalam kolom "Pengikut Halaman" terdapat 12 pengguna yang telah mengikuti dan pada kolom "pesanan" merupakan hasil dari beberapa pengguna yang memesan produk dari halaman fanspage pakan cacing.
Dalam pelaksanaan pertama sampai ketiga bisa diketahui, untuk melakukan sebuah pemasaran dibutuhkan keaktifan dalam mempromosikan sebuah produk tersebut dengan waktu bertahap dan teratur. Bisa diketahui perbandingan dalam proses pelaksanaan pertama sampai pelaksanaan ketiga. Pada Gambar 4 bisa diketahui nilai dari jumlah "tayangan halaman" dari pelaksanaan ke 1 yaitu 7 orang, pelaksanaan ke 2 yaitu 22 orang, dan pelaksanaan 3 yaitu 31 orang. Ini merupakan jumlah orang yang telah melihat halaman dalam fanspage Facebook pakan cacing. Selanjutnya pada kolom "Suka halaman" bisa diketahui pelaksanaan 1 yaitu 2 orang, pelaksanaan ke 2 yaitu 4 orang, dan pelaksanaan 3 yaitu 11 orang. Hal ini adalah orang yang telah menyukai tautan maupun postingan yang dikirim oleh admin pakan cacing ke dalam halaman fanspage tersebut. Serta dalam interaksi postingan hanya ada 2 orang di pelaksanaan 3. Di dalam interaksi ini adalah orang yang mencoba melihat detail dalam halaman fanspage. Dan yang terakhir adalah pengikut halaman, dimana pada kolom ini merupakan beberapa pengguna yang telah mengikut untuk terus ke dalam halaman fanspage pakan cacing ini. Serta diketahui pada pelaksanaan 1 yaitu 2 orang, pelaksanaan 2 yaitu 4 orang dan pelaksanaan 3 yaitu 12 orang.

\section{HASIL DAN PEMBAHASAN}

Dalam pelaksanaan yang telah dilakukan diketahui pada pelaksanaan 1 terdapat 7 pengguna yang telah melihat halaman tersebut. Kemudian 2 pengguna yang menyukai halaman fanspage tersebut. Diikuti dengan 2 pengguna yang 


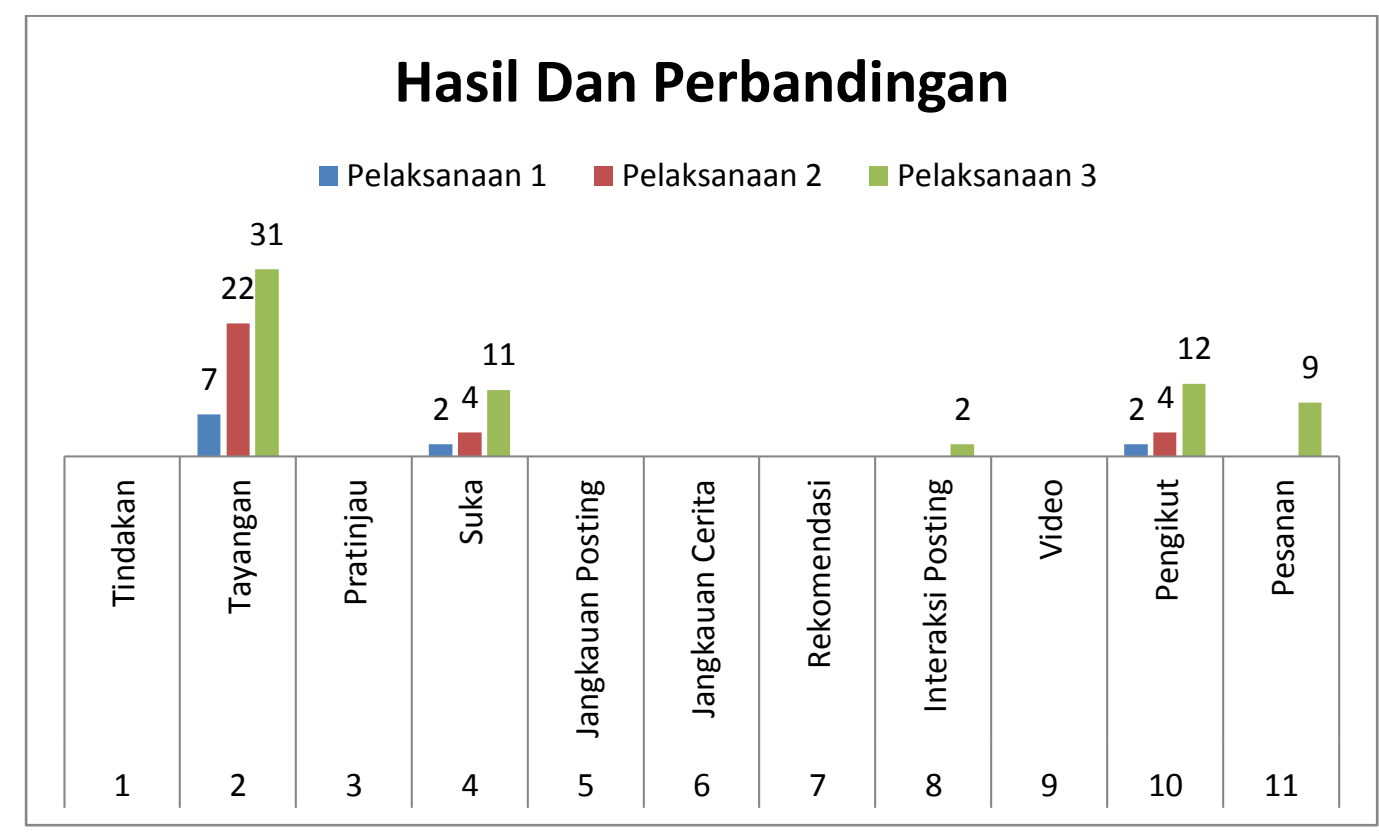

Gambar 4. Hasil Perbandingan

telah melihat dan menjangkau halaman secara detail. Serta 2 pengguna yang mengikut untuk terus berada di dalam halaman fanspage pakan cacing. Kemudian dalam pelaksanaan ke 2 diketahui hasilnya adalah 22 pengguna yang telah melihat halaman fanspage. Serta 4 pengguna telah menyukai halaman dari fanspage pakan cacing dan dalam jangkauan telah diketahui ada 5 pengguna yang telah melihat detail dari fanspage pakan cacing. Dalam fanspage tersebut juga diikuti 4 orang pengguna untuk terus melihat halaman fanspage tersebut. Pada pelaksanaan yang terakhir yang ada pada pelaksanaan ke 3 diketahui hasilnya adalah 31 pengguna yang telah melihat. Serta 11 pengguna yang menyukai halaman tersebut kemudian 5 pengguna telah menjangkau halaman fanspage, dimana para pengguna telah melakukan interaksi detail terhadap fungsi dan manfaat pada halaman fanspage tersebut. Dalam pengikut halaman diketahui 12 pengguna yang mengikuti halaman fanspage, serta 9 pesanan yang di terima dalam produk yang dipasarkan oleh fanspage pakan cacing. Dengan pelaksanaan pertama sampai ketiga ini dapat diketahui bahwa untuk memasarkan sebuah produk di media sosial diperlukan keaktifan dalam mempromosikan sebuah produk secara berkala dan bertahap.

\section{KESIMPULAN DAN SARAN}

Dalam hal ini menjelaskan setiap pelaksanaan yang dilakukan dari pertama sampai ketiga menunjukkan terjadinya sebuah perubahan dari hasil dengan waktu 1 hari. Pada pelaksanaan pertama sampai ketiga memiliki nilai yang berbeda setiap waktunya. Ini membuktikan bahwa setiap perubahan yang diperoleh selama 1 hari telah mendapatkan kenaikan secara berkala. Dan dalam memposting harus memiliki pesan yang singkat dan jelas untuk menarik perhatian pengunjung untuk melihat dan memesan produk pakan cacing tersebut.Kemudian dapat disarankan bahwa untuk memasarkan sebuah produk diperlukan waktu yang teratur dalam pemasaran online. Hal ini akan meningkatkan nilai jual dan mutu para peminat untuk tertarik kepada produk tersebut.

\section{Ucapan Terima Kasih}

Terima kasih atas hibah yang diberikan pada skema Program Kemitraan Masyarakat (PKM) yang dilaksanakan pada tahun 2019 dari Direktur Riset dan Pengabdian Masyarakat (DRPM) Kementerian Riset, Teknologi, dan Pendidikan Tinggi, Kemudian tidak lupa ucapan terima kasih kepada Mitra Pengabdian yaitu CV. RAJ Organik (Rumah Alam Jaya Organik) atas kerja sama dalam proses pengabdian masyarakat. Semoga kerja sama ini berlanjut pada tahun berikutnya.

\section{DAFTAR PUSTAKA}

[1] A. L. Hananto and A. Y. Rahman, "User Experience Measurement On Go-Jek Mobile App In Malang City," 2018 Third Int. Conf. Informatics Comput., pp. 1-6, 2018.

[2] M. Jamil and M. Said, "The Utilization of Internet of Things (IoT) for Multi Sensor Data Acquisition using Thingspeak," VOLT J. Ilm. Pendidik. Tek. Elektro, vol. 3, no. 1, p. 13, 2018.

[3] R. Herlina, E. Susana, N. Widiastuti, and R. Rahmayani, "Manfaat Internet Corporate sebagai Media Relations Hotel Java Retro \&amp; Suites," J. Abdimas BSI J. Pengabdi. Kpd. Masy., vol. 2, no. 1, pp. 32-39, 2019.

[4] N. anggoro Purwatiningsih, A. Fatchiya, and R. S. H. Mulyandari, "Pemanfaatan Internet Dalam Meningkatkan Kinerja Penyuluh Pertanian di Kabupaten Cianjur," Penyuluhan, vol. 14, no. 1, pp. 159-174, 2018.

[5] S. Setiawidayat and A. Y. Rahman, "New method for obtaining Peak Value R and the duration of each cycle of Electrocardiogram," 3rd Int. Conf. Sustain. Inf. Eng. Technol. SIET 2018 - Proc., pp. 77-81, 2018.

[6] A. Y. Rahman, M. Sa'adah, F. W. Setiawan, and E. Supriyanto, "Vice Presidential Election Prediction Period 2019- 2024 using Simple Additive Weighting," 2019.

[7] A. Y. Rahman, S. Sumpeno, and M. H. Purnomo, "Arca Detection and Matching Using Scale Invariant 
Feature Transform (SIFT) Method of Stereo Camera," Proc. - 2017 Int. Conf. Soft Comput. Intell. Syst. Inf. Technol. Build. Intell. Through IOT Big Data, ICSIIT 2017, pp. 66-71, 2017.

[8] A. Y. Rahman, M. Sa'adah, F. W. Setiawan, A. L. Hananto, and E. Supriyanto, "Quality of Service Analysis on Go-Jek Mobile App for Students," pp. 6165, 2018.

[9] D. Setiawan, S. Lestari, D. S. Putra, and M. Azmi, "Pemanfaatan Media Sosial untuk Membangun Sistem E-Learning di SMKN 1 Gunung Talang," INVOTEK J. Inov. Vokasional dan Teknol., vol. 18, no. 1, pp. 7-12, 2018.

[10] M. R. Handika, A. F. Maradona, and G. S. Darma, "Strategi Pemasaran Bisnis Kuliner Menggunakan Influencer," vol. 15, no. 2, pp. 192-203, 2018.

[11] E. Meinawati and R. Baron, "Media Sosial Dan Pembelajaran: Studi Efektivitas Penggunaan Facebook Dalam Pembelajaran Bahasa Inggris," J. Tatsqif, vol. 17, no. 1, pp. 34-51, 2019.

[12] D. Syofiawan, A. L. Fernandes, and Suhida, "PEMANFAATAN MEDIA ONLINE SEBAGAI MEDIA PROMOSI DENGAN MENGGUNAKAN METODE SIMPLE ADDITIVE," vol. 2, no. 2, pp. 716, 2018.

[13] A. S. Prasetyo, "Strategi Komunikasi Pemasaran Bisnis Tiket," vol. 25, no. 1, pp. 74-87, 2017.

[14] A. Y. Rahman, M. Sa'adah, F. W. Setiawan, A. L. Hananto, and E. Supriyanto, "Access Level File using Simple Additive Weighting,” pp. 62-66, 2018.

[15] A. Y. Rahman, S. Sumpeno, and M. H. Purnomo, "Video Minor Stroke Extraction Using Learning Vector Quantization," pp. 1-7, 2017. 